\title{
Design of a reactor cell for modulated excitation Raman and diffuse- reflectance studies of selective catalytic reduction (SCR) catalysts
}

Rob Jeremiah G. Nuguid ${ }^{1,2}$, Davide Ferri ${ }^{1, *}$, Oliver Kröcher ${ }^{1,2}$

${ }^{1}$ Paul Scherrer Institut, CH-5232 Villigen PSI, Switzerland

${ }^{2}$ Institute of Chemical Sciences and Engineering, École polytechnique fédérale de Lausanne (EPFL), CH-1015 Lausanne, Switzerland

*Corresponding author: davide.ferri@psi.ch

ORCID

Rob Jeremiah G. Nuguid: 0000-0003-2351-0751

Davide Ferri: 0000-0002-9354-5231

Oliver Kröcher: 0000-0002-7268-7257

This document is the accepted manuscript version of the following article:

Nuguid, R. J. G., Ferri, D., \& Kröcher, 0. (2019). Design of a reactor cel1 for modulated excitation Raman and diffuse reflectance studies of selective catalytic reduction catalysts. Emission Control science and Technology, 5(4), 307-316. https://doi .org/10.1007/s40825-019-00141-2 


\begin{abstract}
Despite the large pool of spectroscopic studies about selective catalytic reduction (SCR), transient response experiments have not yet been fully utilized to extract key mechanistic and kinetic insights. Here we describe the construction and performance characteristics of a spectroscopic cell that can be used for such an experimental design. The rapid gas exchange in the reaction chamber of the cell makes it amenable to modulated excitation (ME) experimentation. We show case studies wherein this cell was used for Raman, visible, and infrared spectroscopy under ME conditions to investigate the SCR mechanism over three of the most industrially relevant SCR catalysts today $-\mathrm{V}_{2} \mathrm{O}_{5} / \mathrm{TiO}_{2}, \mathrm{Cu}-\mathrm{SSZ}-13$, and Fe-ZSM-5.
\end{abstract}

Keywords: Infrared spectroscopy; Mechanism; Modulated excitation; Operando spectroscopy; Raman spectroscopy; Selective catalytic reduction; UV-Visible spectroscopy 


\section{INTRODUCTION}

Nitrogen oxide $\left(\mathrm{NO}_{\mathrm{x}}\right)$ abatement has always occupied a central position in emission control research [1-4]. The active interest in this topic originates from the highly detrimental effects of $\mathrm{NO}_{\mathrm{x}}$ to human health and the environment. Unmitigated $\mathrm{NO}_{\mathrm{x}}$ pollution not only causes respiratory diseases, but also contributes to ozone layer destruction, photochemical smog formation, and acid rain. Over the years, several $\mathrm{NO}_{\mathrm{x}}$ abatement strategies have been proposed, and some of them have been successfully commercialized [5-7]. Selective catalytic reduction (SCR) is currently the most efficient one [8], and the only viable option for Dieselpowered vehicles and thermal power plants. In this process, the selective reductant $\mathrm{NH}_{3}$ is used to transform $\mathrm{NO}_{\mathrm{x}}$ into environmentally benign molecules. Approximately $90 \%$ of the $\mathrm{NO}_{\mathrm{x}}$ coming from exhaust gas are in the form of $\mathrm{NO}$ [9] and correspondingly, the primary reaction that occurs on the catalytic converter is as follows:

$4 \mathrm{NO}+4 \mathrm{NH}_{3}+\mathrm{O}_{2} \rightarrow 4 \mathrm{~N}_{2}+6 \mathrm{H}_{2} \mathrm{O}$

(Equation 1)

The presence of $\mathrm{NO}_{2}$ in the feed can give rise to the fast SCR reaction:

$2 \mathrm{NO}+2 \mathrm{NO}_{2}+4 \mathrm{NH}_{3} \rightarrow 4 \mathrm{~N}_{2}+6 \mathrm{H}_{2} \mathrm{O}$

(Equation 2)

which occurs at least one order of magnitude faster than Eq. 1 [10]. Diesel oxidation catalysts are positioned in vehicles upstream of an SCR system to partially oxidize $\mathrm{NO}$ into $\mathrm{NO}_{2}$, and allow the fast SCR reaction to proceed.

Various types of SCR catalysts are commercially available. Since their introduction in the 1970 's, $\mathrm{V}_{2} \mathrm{O}_{5} / \mathrm{TiO}_{2}$-based materials have remained to be the most widely used for stationary applications. Their industrial success results from their high activity, good resistance to $\mathrm{SO}_{2}$ poisoning, and moderate cost [11]. However, metal-exchanged zeolites have emerged as the preferred option in automotive systems because they are more adaptable to high space velocity conditions [8]. Cu-based catalysts in particular possess superior activity in the low temperature regime, which is essential for cold start-up and short-distance driving. ZSM-5 
was initially used as the zeolite support, but it had poor stability in the presence of $\mathrm{H}_{2} \mathrm{O}$ or hydrocarbons [12]. Nowadays, the preference for SSZ-13 as the carrier for $\mathrm{Cu}$ is justified by the relatively smaller pores of the zeolite, thereby ensuring unparalleled hydrothermal stability $[13,14]$. Fe-exchanged zeolites have also received attention because of their high activity at higher temperatures: above $450{ }^{\circ} \mathrm{C}, \mathrm{Fe}-\mathrm{ZSM}-5$ outperforms its $\mathrm{Cu}$ counterpart in terms of NO conversion [15]. Fe catalysts are also considerably less susceptible to $\mathrm{N}_{2} \mathrm{O}$ formation than $\mathrm{Cu}$ catalysts, especially at low $\mathrm{NO}_{2}$ feed concentration [16].

The scientific literature abounds with spectroscopic investigations of SCR catalysts, and several debated reaction mechanisms have been proposed based on these studies [17-19]. However, most of these experiments were carried out under steady-state conditions, which are not sufficient to extract in-depth mechanistic and kinetic details about the system beyond the ones achieved so far. Furthermore, real-life automotive catalysts operate under dynamic conditions of temperature, pressure, and reactant composition that are dictated by the driving conditions. Mobile urea-SCR installations for instance rely on periodic urea injection to generate $\mathrm{NH}_{3}$. Lastly, isolation of the structure of the catalytically active species within the large contribution of stationary species remains a challenge.

The aforementioned difficulties can be addressed in laboratory studies by the use of transient spectroscopic studies and, in some cases, modulated excitation (ME) conditions wherein the concentration of one of the reactants is varied repeatedly as a function of time [20]. Such type of experiments relies on the sudden variation of the experimental conditions to induce the largest spectroscopic response in the system. Beside spectrometers with a high temporal resolution and the use of switching valves with sub-second response time, a suitable reactor cell with a low void volume is needed - a requirement that most commercial spectroscopic cells lack. Although commercial cells are suitable for routine in situ studies, 
they cannot exchange gases fast enough for transient response experiments. Special sample holders must be custom-built for this purpose, and various examples exist [21-27].

In mechanistic studies, no single spectroscopic or diffraction technique is self-sufficient. A comprehensive molecular view of the SCR reaction can only be developed from the complementary information offered by different techniques. Raman spectroscopy can directly probe the molecular structure of the catalyst, especially in metal oxide-based systems. Due to their highly polarizable bonds with predominantly covalent character, transition metal oxides such as $\mathrm{V}_{2} \mathrm{O}_{5}$ and $\mathrm{TiO}_{2}$ give rise to intense Raman-active vibrational modes [28]. Ultravioletvisible (UV-Vis) spectroscopy delivers electronic information about the metal active sites. It is especially useful to monitor changes in the oxidation state as many transition metals have characteristic weak $d-d$ transition and intense charge transfer bands in the visible and UV region of the spectrum, respectively [29]. Infrared spectroscopy is the technique of choice to follow the evolution of adsorbed chemical species on a catalyst surface - from the formation of intermediates to the release of products $[28,30]$.

Here we describe in detail the design and characteristics of a custom-built spectroscopic cell with a reduced void volume. Coupled to a suitable set-up, this cell can be used to reproduce the same type of experiment using complementary spectroscopic methods. We demonstrate that the fabricated cell accomplishes its intended purpose for carrying out transient response and ME studies.

\section{METHODS AND MATERIALS}

\subsection{Cell design and experimental set-up}

The cell is presented in Figure 1 and was constructed according to the specifications given in Figures S-1 to S-4. An actual image of the cell is presented in Figure S-5. It is based on the design of a Harrick Scientific spectroscopic cell and is used with a Praying Mantis ${ }^{\mathrm{TM}}$ 
accessory for diffuse reflection. The cell can be used with automatic stages for mapping experiments similar to the commercial cell. Two major innovations contribute to reduce the void volume significantly in the cell. First, the design of the cell body (A; Figure 1) was redesigned to remove the inner void volume present in the commercial cell. This was achieved by positioning the heat cartridge vertically and to exploit it to pre-heat the gas feed to the sample. The body confining the heating cartridge (B) also contains the sample cup (C). The gas feed runs within an annular void space of approximately $4 \mathrm{~mL}$ between $\mathrm{A}$ and $\mathrm{B}$ before meeting the sample in a very similar geometry to the commercial cell. In the current design, the thermocouple used to control the sample temperature (D) is inserted approximately $1 \mathrm{~mm}$ below the sample cup in the same body, while a second thermocouple (E) is placed parallel to this one and is used to record the temperature. For improved temperature control and monitoring, another thermocouple may be inserted perpendicular to the sample cup. Second, the cell cover consists of just one flat window (F) instead of two windows arranged in a dome-like configuration, as it is the case in the commercial cell. Although this geometry is not optimum for diffuse reflectance because of the specular component, the cell can be lifted up until the signals of the sample, not necessarily the amplitude of the IR signal, are maximized. This is shown in Figure 2 for a zeolite sample. The IR signals from the zeolite framework are clearly discernible in the single beam spectrum from 2000 to $1000 \mathrm{~cm}^{-1}$. We have also exploited this geometry successfully in a different cell design [24]. The moveable clamps used to secure the window on top of the spectroscopic cell follow the design of the commercial cell.

We have demonstrated earlier that the cell can be used as a reactor for SCR studies [3133]. The cell is the heart of a setup enabling mixing gases and consisting of a main gas feed line and four auxiliary lines. The gas through the four auxiliary lines can be mixed with the one flowing through the main line using four independent solenoid valves $(5 \mathrm{~ms}$ response, 
Series 9; Parker) controlled by the Rapid Scan TRS mode of the OPUS spectroscopy software (Bruker). The exit of the cell can be interfaced with an IR spectrometer or a mass spectrometer. All lines are stainless steel. Water is generated in situ from precise flows of $\mathrm{H}_{2}$ and $\mathrm{O}_{2}$ through a $\mathrm{Pt} / \mathrm{Al}_{2} \mathrm{O}_{3}$ catalyst. This allows for a pulsation-free feeding of water.

The same cell and the same setup have been used for all spectroscopic experiments described in the following.

\subsection{Residence time distribution properties}

The residence time distribution (RTD) analysis was performed using a pulse input experiment $[22,34]$. NO $(2 \mu \mathrm{L})$ was introduced in an Ar-only gas feed $\left(100 \mathrm{~mL} \cdot \mathrm{min}^{-1}\right)$ through the cell using a four-way valve. The concentration decay of the tracer was monitored using a Pffeifer VacuumOmniStar ${ }^{\mathrm{TM}}$ mass spectrometer (MS) that was connected downstream of the cell. The experiment was also repeated in a stainless steel gas line bypassing the reactor cell and flowing directly to the MS.

The RTD function $E(t)$ was calculated according to the following formula:

$$
E(t)=\frac{C(t)}{\int_{0}^{\infty} C(t) d t}
$$

where $v$ is the volumetric flow rate, $C(t)$ is the concentration of the tracer leaving the reactor at time $t$. Since NO concentration is directly proportional to the mass-to-charge ratio of 30 $(\mathrm{m} / \mathrm{z}=30)$, the latter was used in the calculations. Integrating $E(t)$ over a time gives the fraction of the gas that has resided in the reactor for that specific period, thus:

$$
\int_{0}^{\infty} E(t) d t=1
$$

Experimentally, this relationship is confirmed since the MS signal at $\mathrm{m} / \mathrm{z}=30$ eventually returns to the baseline value after each tracer injection.

An important parameter that can be derived from the RTD analysis is the mean residence time $t_{m}$ : 


$$
t_{m}=\int_{0}^{\infty} t E(t) d t
$$

This is the average time that a molecule spends within the reactor. For transient response studies, a spectroscopic cell with a low $t_{m}$ is desired.

\subsection{Catalyst synthesis and cell pre-treatment}

The catalysts used in this study were $2 \mathrm{wt} \% \mathrm{~V}_{2} \mathrm{O}_{5} / \mathrm{TiO}_{2}, 2.6 \mathrm{wt} \% \mathrm{Fe}-\mathrm{ZSM}-5$, and $1.6 \mathrm{wt} \%$ Cu-SSZ-13.

$\mathrm{V}_{2} \mathrm{O}_{5} / \mathrm{TiO}_{2}$ was prepared by wet impregnation. A sufficient amount of $\mathrm{NH}_{4} \mathrm{VO}_{3}$ (Fluka, $>99.0 \%$ ) was dissolved in water at $60^{\circ} \mathrm{C}$, and was mixed for $1 \mathrm{~h}$ with $\mathrm{TiO}_{2}$ (DT-51, Cristal)

calcined at $550^{\circ} \mathrm{C}$. After removal of water under reduced pressure, the sample was calcined in a muffle furnace at $600{ }^{\circ} \mathrm{C}$ for $5 \mathrm{~h}$.

Fe-ZSM-5 was prepared by ion exchange. ZSM-5 (Si/Al=13; SM-27 P, Süd-Chemie) was mixed with a solution of $0.1 \mathrm{M} \mathrm{FeSO}_{4} \cdot 7 \mathrm{H}_{2} \mathrm{O}$ (Sigma-Aldrich, $>99.0 \%$ ) at room temperature for $6 \mathrm{~h}$. The sample was filtered, washed thrice with distilled water, and dried at $120{ }^{\circ} \mathrm{C}$ overnight. Then, it was calcined at $600{ }^{\circ} \mathrm{C}$ for $6 \mathrm{~h}$.

$\mathrm{Cu}-\mathrm{SSZ}-13$ was prepared by hydrothermal synthesis and ion exchange, as described in detail elsewhere [35]. Briefly, the synthesized SSZ-13 was ion-exchanged with a solution of $0.1 \mathrm{M} \mathrm{CuSO}_{4} \cdot 5 \mathrm{H}_{2} \mathrm{O}$ (Sigma-Aldrich, $>98 \%$ ) at $80{ }^{\circ} \mathrm{C}$ for $4 \mathrm{~h}$, filtered, washed thrice with distilled water, and dried at $120{ }^{\circ} \mathrm{C}$ overnight. The sample was then calcined at $600{ }^{\circ} \mathrm{C}$ for 4 h.

Approximately $50 \mathrm{mg}$ of each catalyst powder $(100-150 \mu \mathrm{m})$ were loaded in the spectroscopic cell. Prior to each experiment, the sample was dehydrated in $5 \mathrm{vol} \% \mathrm{O}_{2} / \mathrm{Ar}$ $\left(100 \mathrm{~mL} \cdot \mathrm{min}^{-1}\right)$ at $450{ }^{\circ} \mathrm{C}$ for $1 \mathrm{~h}$.

\subsection{ME-Raman spectroscopy of $\mathrm{V}_{2} \mathrm{O}_{5} / \mathrm{TiO}_{2}$}

Raman spectra were collected using a Kaiser RamanRXN-1 ${ }^{\mathrm{TM}}$ analyzer equipped with a fiber optics probe and a 785-nm laser. Spectra were collected from $1500 \mathrm{~cm}^{-1}$ to $100 \mathrm{~cm}^{-1}$ at a 
resolution of $2 \mathrm{~cm}^{-1}$ with a laser power of $100 \mathrm{~mW}$ and exposure time of $0.5 \mathrm{~s}$. No sample damage was observed under these conditions [33].

The cell was equipped with a 2-mm thick sapphire window (Crystran) and attached to a Praying Mantis ${ }^{\mathrm{TM}}$ accessory. The fiber optics probe was mounted perpendicular to the cell.

ME was performed by pulsing 500 ppm of $\mathrm{NO}$ every $30 \mathrm{~s}$ in a gas feed of $500 \mathrm{ppm} \mathrm{NH}_{3}$, $2 \mathrm{vol} \% \mathrm{H}_{2} \mathrm{O}, 5 \mathrm{vol} \% \mathrm{O}_{2}$ balanced in $\mathrm{Ar}\left(100 \mathrm{~mL} \cdot \mathrm{min}^{-1}\right)$. Each period consists of 30 consecutive spectra, which are collected every 2 s. At least 20 periods were averaged to generate the phase-resolved spectra.

\subsection{ME-DR-Vis Spectroscopy of Cu-SSZ-13}

Diffuse reflectance visible (DR-Vis) spectra were recorded using an Agilent Cary 4000 UV-Vis spectrometer. The instrument collected spectra from $350 \mathrm{~nm}$ to $800 \mathrm{~nm}$ at a resolution of $1.1 \mathrm{~nm}$ and scan rate of $16.7 \mathrm{~nm} \cdot \mathrm{s}^{-1}$. Acquisition in the $\mathrm{UV}$ region was not performed because the time resolution would be compromised by changing the light source during the measurement.

The cell was equipped with a $2-\mathrm{mm}$ thick $\mathrm{CaF}_{2}$ window (Crystran) and attached to a Praying Mantis ${ }^{\mathrm{TM}}$ Diffuse Reflection Accessory in the compartment of the UV-Vis spectrometer.

ME was performed by pulsing $1000 \mathrm{ppm} \mathrm{NO}$ every $120 \mathrm{~s}$ in a gas feed of $1000 \mathrm{ppm} \mathrm{NH}_{3}$, 5 vol $\% \mathrm{O}_{2}$ balanced in $\mathrm{Ar}\left(100 \mathrm{~mL} \cdot \mathrm{min}^{-1}\right)$. Each period consists of 10 consecutive spectra, which are collected every 24 s. At least 10 periods were averaged to generate the phaseresolved spectra.

\subsection{ME-DRIFT Spectroscopy of Fe-ZSM-5}

Diffuse reflectance infrared Fourier transform (DRIFT) spectra were collected using a Bruker Vertex70 spectrometer equipped with a $\mathrm{HgCdTe}$ detector. Spectra were recorded in 
the range of 4000 to $800 \mathrm{~cm}^{-1}$ at a resolution of $4 \mathrm{~cm}^{-1}$ and scanner velocity of $80 \mathrm{kHz}$. The sample and background spectrum resulted from 10 and 50 scans, respectively.

The cell was equipped with a 2-mm thick $\mathrm{CaF}_{2}$ window (Crystran) and attached to a Praying Mantis ${ }^{\mathrm{TM}}$ accessory in the compartment of the IR spectrometer.

ME was performed by pulsing 1000 ppm NO every $60 \mathrm{~s}$ in a gas feed of $1000 \mathrm{ppm} \mathrm{NH}_{3}$, $5 \mathrm{vol} \% \mathrm{O}_{2}$ balanced in $\mathrm{Ar}\left(100 \mathrm{~mL} \cdot \mathrm{min}^{-1}\right)$. Each period consists of 120 consecutive spectra, which are collected every $1 \mathrm{~s}$. At least 20 periods were averaged to generate the phaseresolved spectra.

\subsection{Phase-sensitive detection (PSD)}

The time-resolved spectra were converted into phase-resolved spectra using the following equation [36]:

$$
I\left(\varphi^{P S D}\right)=\frac{2}{T} \int_{0}^{T} I(t) \sin \left(k \omega t+\varphi^{P S D}\right) d t
$$

where $\mathrm{T}$ is the modulation period, $\mathrm{I}(\mathrm{t})$ is the intensity or absorbance in the time-resolved spectra, $\mathrm{k}$ is the demodulation index ( $\mathrm{k}=1$ in this work), $\omega$ is the stimulation frequency, and $\varphi$ is the phase angle. A Matlab script was used to process the spectra.

\section{RESULTS AND DISCUSSION}

\subsection{RTD analysis and mean residence time}

Residence time distribution (RTD) analysis was performed to check the efficiency of gas exchange inside the reactor. The RTD profile of the NO pulse through the spectroscopic cell was calculated according to Equation 1, and the results are shown in Table 1 and Figure 3. At a flow rate of $100 \mathrm{~mL} \cdot \mathrm{min}^{-1}$, the RTD behaviors of the NO pulse through the cell and bypass show very similar shapes. The decay profile of the NO pulse that passed through the cell exhibited tailing, but the effect was offset by the high flow rate. 
Decreasing the flow rate broadened the concentration decay curves considerably because of a more pronounced effect of the extra cell volume. The NO concentration reached its maximum value with a considerable time delay - a feature that was not observed at 100 $\mathrm{mL} \cdot \mathrm{min}^{-1}$. At a flow rate of $25 \mathrm{~mL} \cdot \mathrm{min}^{-1}$, the time at which the MS signal decayed to $90 \%$ of its initial value ( $\left.\mathrm{t}_{90}\right)$ was doubled when NO was injected through the cell instead of the bypass.

In all of the decay profiles presented in Figure 3, the tailing observed as the MS signal returned to the baseline value slowly after the pulse is most probably due to stagnant regions or residual void zones in the cell where the gas exchange might be less efficient. Such profile is characteristic of a non-ideal continuous-stirred tank reactor (CSTR) [34]. Indeed, the commercial cell which served as the basis of the current cell design was reported to be a CSTR according to recently published studies $[22,23]$. It is also worth noting that the bypass line also showed a CSTR profile, which is contributed mainly by the MS detection chamber [23].

In modulated excitation experiments, the system will eventually reach a quasi-equilibrium state no matter how large the void volume of the reactor is. However, it is preferred that the concentration of the reactants in the gas phase is changed as much as possible in each half period because this will induce a more prominent change in the corresponding phase-resolved spectra. It is for this reason that the void volume of the spectroscopic cell must be as low as possible. For instance, when 1000 ppm NO is pulsed in a feed containing $\mathrm{NH}_{3}$ (i.e., SCR on/off conditions), a reactor with appropriate gas exchange capabilities will allow the NO concentration to drop as close to 0 ppm as possible when the supply is off. On the other hand, a spectroscopic cell with a high void volume might always have various levels of residual NO in the gas phase even though the supply is off. As a result, SCR is always on and there will be weaker spectral changes to observe after PSD treatment. 
In the following ME experiments, the total gas flow was fixed at $100 \mathrm{~mL} \cdot \mathrm{min}^{-1}$. The mean residence time $\left(t_{\mathrm{m}}\right)$ under these conditions was calculated from Equation 5 to be approximately $22.9 \mathrm{~s}$ (Table 1). As a result, we ensured that the half-period of any ME experiment performed with the cell was well above this value (i.e., $30 \mathrm{~s}$ for Raman spectroscopy, $60 \mathrm{~s}$ for DRIFT spectroscopy, and $120 \mathrm{~s}$ for DR-Vis spectroscopy).

\subsection{ME-Raman spectroscopy of $\mathrm{V}_{2} \mathrm{O}_{5} / \mathrm{TiO}_{2}$}

Figure 4a,b shows the time-resolved Raman spectra and the corresponding phase-resolved spectra of $\mathrm{V}_{2} \mathrm{O}_{5} / \mathrm{TiO}_{2}$ obtained under repeated $\mathrm{NO}$ pulses. The strong bands at 395,516 , and $636 \mathrm{~cm}^{-1}$ are characteristic of crystalline $\mathrm{TiO}_{2}$ in the anatase phase, and correspond to $\mathrm{B}_{1 \mathrm{~g}}$, $\mathrm{A}_{2 \mathrm{~g}}+\mathrm{B}_{1 \mathrm{~g}}$, and $\mathrm{E}_{\mathrm{g}}$ modes, respectively $[37,38]$. The $\mathrm{B}_{1 \mathrm{~g}}$ mode has a second overtone at around $800 \mathrm{~cm}^{-1}$, which is visible as a weak band in the spectrum. The peak at around $1018 \mathrm{~cm}^{-1}$ is readily assigned to the $v(\mathrm{~V}=\mathrm{O})$ stretch mode, which is centered at $1031 \mathrm{~cm}^{-1}$ under dry, oxidizing conditions [39]. The absence of the bulk $\mathrm{V}_{2} \mathrm{O}_{5}$ peak at $995 \mathrm{~cm}^{-1}$ indicates that the $\mathrm{VO}_{\mathrm{x}}$ species are well-dispersed in agreement with the submonolayer coverage of the catalyst $\left(2 \mathrm{VO}_{\mathrm{x}} \cdot \mathrm{nm}^{-2}\right)[40]$

Spectral changes were already evident in the time-resolved spectra but were further amplified after PSD. All the three characteristic peaks of $\mathrm{TiO}_{2}$ were strongly perturbed by the periodic NO pulses and thus appeared in the in-phase spectrum shown in Figure 4b. All other phase-resolved spectra showed the same features but with decreasing intensity. On the other hand, the Raman signal of $\mathrm{VO}_{\mathrm{x}}$ was barely discernable even in the phase-resolved spectra. Hence, it appears that $\mathrm{TiO}_{2}$ underwent the most prominent spectral changes during the concentration modulation. 
The main role of the support material is to provide a high-surface-area environment that can disperse the active phase. In some instances, however, supports may have a non-innocent role in the catalytic process. In the case of $\mathrm{NH}_{3}-\mathrm{SCR}, \mathrm{TiO}_{2}$ provides vacant $\mathrm{Ti}^{4+}$ sites, where $\mathrm{NH}_{3}$ can adsorb through a Lewis acid-base interaction [17]. Hence, $\mathrm{TiO}_{2}$ serves as a reservoir of adsorbed $\mathrm{NH}_{3}$ molecules which can be delivered to the active sites to react if $\mathrm{NO}$ is present. In our experiment, $\mathrm{NH}_{3}$ was always present in the gas feed ensuring that the $\mathrm{VO}_{\mathrm{x}}$ sites can be supplied with $\mathrm{NH}_{3}$ molecules directly from the gas phase. However, the fact that $\mathrm{TiO}_{2}$ peaks are present in the phase-resolved spectra suggests that the delivery of substrate molecules from $\mathrm{TiO}_{2}$ to $\mathrm{VO}_{\mathrm{x}}$ is still at work. Mechanistically, this is intuitively correct since bound $\mathrm{NH}_{3}$ molecules are closer in proximity and easier to access than those that originate from the gas phase. In fact, some studies postulate that $\mathrm{NH}_{3}$ adsorption occurs initially at $\mathrm{TiO}_{2}$ before $\mathrm{VO}_{\mathrm{x}}$ sites [41]. This molecular behavior is consistent with the results of our $\mathrm{ME}$ experiments.

Most of the $\mathrm{VO}_{\mathrm{x}}$ species were coordinated with $\mathrm{NH}_{3}$ and water present in the feed. This is the reason for the position of the $v(V=O)$ mode in the time-resolved spectra at $1018 \mathrm{~cm}^{-1}$ instead of $1031 \mathrm{~cm}^{-1}$ [42]. The faint signal of $\mathrm{VO}_{\mathrm{x}}$ in the phase-resolved spectra results from the constant presence of $\mathrm{NH}_{3}$ molecules in the gas phase. The reaction between $\mathrm{NO}$ and adsorbed $\mathrm{NH}_{3}$ should result ultimately in the production of coordinatively unsaturated $\mathrm{VO}_{\mathrm{x}}$ sites. However, this process is so fast that the signal of "free" $\mathrm{VO}_{\mathrm{x}}$ is not observed in the phase-resolved spectra under the time scale employed in the experiment. On the other hand, the transfer of $\mathrm{NH}_{3}$ from neighboring $\mathrm{TiO}_{2}$ to the active sites is probably slower, which explains why the characteristic peaks of $\mathrm{TiO}_{2}$ are present in the phase-resolved spectra. In a complementary experiment where $\mathrm{NH}_{3}$ is pulsed in a gas feed containing a constant concentration of $\mathrm{NO}$, the signal of coordinatively unsaturated $\mathrm{VO}_{\mathrm{x}}$ species was present in the phase-resolved spectra [33]. This proves that vacant $\mathrm{VO}_{\mathrm{x}}$ species are indeed formed during 
the reaction cycle and can be observed when a strongly adsorbing species such as $\mathrm{NH}_{3}$ is not constantly present.

To confirm that the observed effect is in fact due to the SCR reaction, a control experiment was performed in the absence of SCR activity (Figure 4c,d). This was achieved by pulsing $\mathrm{Ar}$ in a gas feed containing 2 vol $\% \mathrm{H}_{2} \mathrm{O}$ and 5 vol\% $\mathrm{O}_{2}$ balanced in Ar. Although the time-resolved spectra showed all of the expected signals of $\mathrm{VO}_{\mathrm{x}}$ and $\mathrm{TiO}_{2}$, the phaseresolved spectra did not present any signal. This means that neither $\mathrm{VO}_{\mathrm{x}}$ nor $\mathrm{TiO}_{2}$ was perturbed by the inert gas pulsing.

\subsection{ME-DR-Vis Spectroscopy of Cu-SSZ-13}

The active $\mathrm{Cu}$ site in the catalyst changes reversibly between two oxidation states (i.e., +2 and +1 ) during the course of the SCR reaction [19]. $\mathrm{Cu}(\mathrm{II})$ exhibits a $d-d$ transition band in the region of 500-1100 $\mathrm{nm}$ and when it is supported on a zeolite, it has an additional band at 220-380 nm due to ligand-to-metal charge transfer (LMCT) [43]. In contrast, $\mathrm{Cu}(\mathrm{I})$ does not possess a $d$ - $d$ transition band because of its fully filled $3 d$ shell. Hence, the reversible $\mathrm{Cu}(\mathrm{II}) \leftrightarrow \mathrm{Cu}$ (I) redox changes in $\mathrm{Cu}-\mathrm{SSZ}-13$ can be monitored by following the appearance/disappearance of the characteristic bands of $\mathrm{Cu}(\mathrm{II})$.

The time-resolved and phase-resolved DR-Vis spectra as a result of repeated NO pulsing are presented in Figure 5a,b. The time-resolved spectra show very shallow bands in the region of 350-800 $\mathrm{nm}$, but no obvious changes were observed. The difference spectra between $\mathrm{Cu}-\mathrm{SSZ}-13$ under $\mathrm{NH}_{3}$ and $\mathrm{NH}_{3} / \mathrm{NO}$ gas feeds could potentially reveal the characteristic $\mathrm{Cu}(\mathrm{II})$ bands, but the signal-to-noise-ratio is low (Figure S-6). Hence, the application of PSD is justified to accentuate the spectral changes. The in-phase spectrum in Figure $4 \mathrm{~b}$ is very similar to the difference spectrum and exhibits a broad band above $500 \mathrm{~nm}$ that may be associated with the $d-d$ transition band of $\mathrm{Cu}(\mathrm{II})$. The band extending below 430 
nm originates from LMCT (in particular, $\mathrm{O}^{2-} \rightarrow \mathrm{Cu}^{2+}$ ) and is not complete in the UV region because the acquisition was stopped at $350 \mathrm{~nm}$ to meet the required time resolution. These two bands vary in-phase (i.e., they increase and decrease simultaneously) because they both originate from the same chemical entity. All other phase-resolved spectra show only intensity variations of these two features.

Without SCR activity (i.e., in the absence of NO), most of the $\mathrm{Cu}$ species are in the +2 oxidation state, according to the generally accepted reaction mechanism [19]. The presence of both $\mathrm{NH}_{3}$ and $\mathrm{NO}$ is needed to drive the reduction of $\mathrm{Cu}(\mathrm{II})$ to $\mathrm{Cu}(\mathrm{I})$, which is coordinated to both reactants and from which the nitrosamide intermediate forms. Although $\mathrm{NH}_{3}$ alone can reduce $\mathrm{Cu}(\mathrm{II})$ in some $\mathrm{Cu}$-based catalysts [44], temperatures higher than $250{ }^{\circ} \mathrm{C}$ are required. It is therefore the NO pulsing that induces the redox process in the experiment presented in Figure 5.

Also in this case, a control experiment was performed in the absence of SCR activity by repeated Ar pulses (Figure 5c,d). No signal was observed in the phase-resolved spectrum, which confirms that the bands observed in Figure $5 \mathrm{~b}$ clearly originate from the redox process of the $\mathrm{Cu}$ sites during SCR activity.

\subsection{ME-DRIFT Spectroscopy of Fe-ZSM-5}

Figure 6a,b shows the time-resolved and phase-resolved DRIFT spectra as a result of NO pulses in $\mathrm{NH}_{3}$ while Figure $6 \mathrm{c}$,d shows the equivalent set of spectra as a result of Ar pulses in $\mathrm{NH}_{3}$. The time-resolved spectra of both experiments are practically identical - they are both dominated by the signal contribution from adsorbed water and $\mathrm{NH}_{3}$. This is equally evident in the stretching region in $3500-2500 \mathrm{~cm}^{-1}$ and the bending region $\left(1750-1250 \mathrm{~cm}^{-1}\right)$ as well. As a result, it is hard to rationalize the presence of other adsorbates and intermediates on the catalyst surface. $\mathrm{NO}$, for instance, is also expected to adsorb on the catalyst under these experimental conditions [45]. Some studies also hinted at the formation of NO-derived 
species such as nitrates, especially at lower temperatures [46]. However, the weak signal of adsorbed $\mathrm{NO}$ and its potential derivatives compared to water and $\mathrm{NH}_{3}$ precludes their unequivocal identification in the time-resolved spectra.

On the contrary, the phase-resolved spectra uncovered substantial differences between the two experiments. When NO was pulsed, several signals were perturbed and appeared in the phase-resolved spectra. For example, hydroxyl $\left(-\mathrm{OH} ; 3650 \mathrm{~cm}^{-1}\right)$ and residual sulfate $\left(-\mathrm{SO}_{4}\right.$; $\left.1365 \mathrm{~cm}^{-1}\right)$ from the ion-exchange procedure, and adsorbed $\mathrm{NH}_{3}\left(3350-3150 \mathrm{~cm}^{-1}\right)$ and nitrosyl $\left(\mathrm{NO}^{+} ; 2139 \mathrm{~cm}^{-1}\right)$ species were perturbed. The $-\mathrm{OH}$ and $-\mathrm{SO}_{4}$ groups varied out-ofphase (i.e., exhibited opposite signal variation) with $\mathrm{NH}_{3}$ and $\mathrm{NO}^{+}$because they are being titrated upon adsorption. When only Ar was pulsed (Figure 6c,d), the apparent signals in the selected phase-resolved spectrum are negligible compared with the experiment under SCR conditions. Furthermore, the presence of the phase-resolved signal of $\mathrm{NH}_{3}$ in Figure $6 \mathrm{~b}$ suggests that they are being consumed during the NO pulsing, proving the occurrence of the SCR reaction.

The peaks at 3344 and $3277 \mathrm{~cm}^{-1}$ in Figure 6a correspond to $\mathrm{NH}_{3}$ adsorbed on BrønstedLowry sites while the one at $3174 \mathrm{~cm}^{-1}$ originate from $\mathrm{NH}_{3}$ bound to Lewis acid sites. The former are present in the zeolite framework due to the charge imbalance of Al-O-Si bonds while the latter can be attributed predominantly to the coordinatively unsaturated Fe sites. In the time-resolved spectra, it is hard to differentiate from the two adsorption sites because adsorbed water also provides a broad overlapping signal in this region of the spectrum. However, the three characteristic N-H bending peaks were revealed after PSD treatment. Hence, it appears from the phase-resolved spectra that both the active Fe sites and the support (Brønsted-Lowry sites) coordinate with $\mathrm{NH}_{3}$ molecules. Steady-state catalytic tests have revealed that the metal-free ZSM-5 support did not exhibit any appreciable SCR activity at $250{ }^{\circ} \mathrm{C}$ (and even up to $450{ }^{\circ} \mathrm{C}$ ). This means that it is the Fe active site that is solely 
responsible for the SCR activity, which rationalizes the perturbation of Lewis-bound $\mathrm{NH}_{3}$ due to $\mathrm{NO}$ pulses. However, $\mathrm{NH}_{3}$ bound to Brønsted-Lowry sites were also perturbed by $\mathrm{NO}$, indicating that during the pulse duration, they might be transferred to Fe sites to react as well.

\section{CONCLUSIONS}

We have presented a reactor cell with a low void volume that can be used for ME spectroscopic studies such as (1) Raman spectroscopy of $\mathrm{V}_{2} \mathrm{O}_{5} / \mathrm{TiO}_{2}$; (2) DR-Vis spectroscopy of Cu-SSZ-13; and (3) DRIFT spectroscopy of Fe-ZSM-5. Due to the low void volume of the cell, the gases were exchanged very efficiently in every pulse sequence, which induced large spectroscopic response after PSD treatment. The results presented here are obviously not sufficient to draw full mechanistic conclusions; rather, they are case studies targeted to prove the suitability of the cell for transient response and ME experimentation. The demonstrated versatility of the cell with regard to various spectroscopic techniques paves the way for implementing time-resolved structural studies which are truly complementary with one another.

\section{ACKNOWLEDGMENTS}

The authors acknowledge the financial support from the Swiss National Science Foundation (SNF, Project \#200021_172669/1). The authors are grateful to H. Altorfer for the cell drawings, M. Hottinger for the cell fabrication, and P. Hottiger for the electrical connections. This project was carried out in the framework of the Swiss Competence Center for Energy Research (SCCER) BIOSWEET program.

\section{Conflict of interest}

On behalf of all authors, the corresponding author states that there is no conflict of interest. 


\section{REFERENCES}

1. Kummer, J.T.: Catalysts for automobile emission control. Progress in Energy and Combustion Science 6(2), 177-199 (1980).

2. Cooper, B.J.: Challenges in Emission Control Catalysis for the Next Decade. Platinum Metals Review 38(1), 2-10 (1994).

3. Jobson, E.: Future Challenges in Automotive Emission Control. Topics in Catalysis 28(1), 191-199 (2004).

4. Johnson, T.: Vehicular Emissions in Review. SAE International Journal of Engines 9(2), 1258-1275 (2016).

5. Tayyeb Javed, M., Irfan, N., Gibbs, B.M.: Control of combustion-generated nitrogen oxides by selective non-catalytic reduction. Journal of Environmental Management 83(3), 251-289 (2007).

6. Cheng, X., Bi, X.T.: A review of recent advances in selective catalytic $\mathrm{NO}_{\mathrm{x}}$ reduction reactor technologies. Particuology 16, 1-18 (2014).

7. Roy, S., Baiker, A.: NOx Storage-Reduction Catalysis: From Mechanism and Materials Properties to Storage-Reduction Performance. Chemical Reviews 109(9), 4054-4091 (2009).

8. Kröcher, O.: Chapter 9 Aspects of catalyst development for mobile urea-SCR systems From Vanadia-Titania catalysts to metal-exchanged zeolites. In: Granger, P., Pârvulescu, V.I. (eds.) Studies in Surface Science and Catalysis, vol. 171. pp. 261289. Elsevier, (2007).

9. Nova, I., Tronconi, E.: Urea-SCR Technology for deNO ${ }_{x}$ After Treatment of Diesel Exhausts. Springer, New York (2014).

10. Ciardelli, C., Nova, I., Tronconi, E., Chatterjee, D., Bandl-Konrad, B.: A "Nitrate Route" for the low temperature "Fast SCR" reaction over a $\mathrm{V}_{2} \mathrm{O}_{5}-\mathrm{WO}_{3} / \mathrm{TiO}_{2}$ commercial catalyst. Chemical Communications(23), 2718-2719 (2004).

11. Amiridis, M., Wachs, I., Deo, G., Jehng, J.-M., Soung Kim, D.: Reactivity of $\mathrm{V}_{2} \mathrm{O}_{5}$ Catalysts for the Selective Catalytic Reduction of $\mathrm{NO}$ by $\mathrm{NH}_{3}$ : Influence of Vanadia Loading, $\mathrm{H}_{2} \mathrm{O}$, and $\mathrm{SO}_{2}$. Journal of Catalysis 161, 247-253 (1996).

12. Kharas, K.C.C., Robota, H.J., Liu, D.J.: Deactivation in Cu-ZSM-5 lean-burn catalysts. Applied Catalysis B: Environmental 2(2), 225-237 (1993).

13. Kwak, J.H., Tonkyn, R.G., Kim, D.H., Szanyi, J., Peden, C.H.F.: Excellent activity and selectivity of Cu-SSZ-13 in the selective catalytic reduction of $\mathrm{NO}_{x}$ with $\mathrm{NH}_{3}$. Journal of Catalysis 275(2), 187-190 (2010).

14. Wang, J., Zhao, H., Haller, G., Li, Y.: Recent advances in the selective catalytic reduction of $\mathrm{NO}_{x}$ with $\mathrm{NH}_{3}$ on $\mathrm{Cu}-\mathrm{Chabazite}$ catalysts. Applied Catalysis B: Environmental 202, 346-354 (2017).

15. Kamasamudram, K., Currier, N., Szailer, T., Yezerets, A.: Why Cu- and Fe-Zeolite SCR Catalysts Behave Differently At Low Temperatures. SAE International Journal of Fuels and Lubricants 3(1), 664-672 (2010).

16. Colombo, M., Nova, I., Tronconi, E.: A comparative study of the $\mathrm{NH}_{3}-\mathrm{SCR}$ reactions over a Cu-zeolite and a Fe-zeolite catalyst. Catalysis Today 151(3), 223-230 (2010).

17. Ramis, G., Busca, G., Bregani, F., Forzatti, P.: Fourier transform-infrared study of the adsorption and coadsorption of nitric oxide, nitrogen dioxide and ammonia on vanadia-titania and mechanism of selective catalytic reduction. Applied Catalysis 64, 259-278 (1990). 
18. Topsøe, N.-Y.: Mechanism of the Selective Catalytic Reduction of Nitric Oxide by Ammonia Elucidated by in Situ On-Line Fourier Transform Infrared Spectroscopy. Science 265(5176), 1217 (1994).

19. Janssens, T.V.W., Falsig, H., Lundegaard, L.F., Vennestrøm, P.N.R., Rasmussen, S.B., Moses, P.G., Giordanino, F., Borfecchia, E., Lomachenko, K.A., Lamberti, C., Bordiga, S., Godiksen, A., Mossin, S., Beato, P.: A Consistent Reaction Scheme for the Selective Catalytic Reduction of Nitrogen Oxides with Ammonia. ACS Catalysis 5(5), 2832-2845 (2015).

20. Müller, P., Hermans, I.: Applications of Modulation Excitation Spectroscopy in Heterogeneous Catalysis. Industrial \& Engineering Chemistry Research 56(5), 1123 1136 (2017).

21. Meunier, F.C.: The design and testing of kinetically-appropriate operando spectroscopic cells for investigating heterogeneous catalytic reactions. Chemical Society Reviews 39(12), 4602-4614 (2010).

22. Srinivasan, P.D., Nitz, S.R., Stephens, K.J., Atchison, E., Bravo-Suarez, J.J.: Modified Harrick reaction cell for in situ/operando fiber optics diffuse reflectance UV-visible spectroscopic characterization of catalysts. Applied Catalysis A: General 561, 7-18 (2018).

23. Patil, B.S., Srinivasan, P.D., Atchison, E., Zhu, H., Bravo-Suárez, J.J.: Design, modelling, and application of a low void-volume in situ diffuse reflectance spectroscopic reaction cell for transient catalytic studies. Reaction Chemistry \& Engineering 4(4), 667-678 (2019).

24. Chiarello, G.L., Nachtegaal, M., Marchionni, V., Quaroni, L., Ferri, D.: Adding diffuse reflectance infrared Fourier transform spectroscopy capability to extended x-rayabsorption fine structure in a new cell to study solid catalysts in combination with a modulation approach. Review of Scientific Instruments 85(7), 074102 (2014).

25. Schubert, M.M., Häring, T.P., Bräth, G., Gasteiger, H.A., Behm, R.J.: New DRIFTS Cell Design for the Simultaneous Acquisition of IR Spectra and Kinetic Data Using OnLine Product Analysis. Appl. Spectrosc. 55(11), 1537-1543 (2001).

26. Bansode, A., Guilera, G., Cuartero, V., Simonelli, L., Avila, M., Urakawa, A.: Performance and characteristics of a high pressure, high temperature capillary cell with facile construction for operando x-ray absorption spectroscopy. Review of Scientific Instruments 85(8), 084105 (2014).

27. Dal Santo, V., Dossi, C., Fusi, A., Psaro, R., Mondelli, C., Recchia, S.: Fast transient infrared studies in material science: development of a novel low dead-volume, high temperature DRIFTS cell. Talanta 66(3), 674-682 (2005).

28. Wachs, I.E.: Raman and IR studies of surface metal oxide species on oxide supports: Supported metal oxide catalysts. Catalysis Today 27(3), 437-455 (1996).

29. Weckhuysen, B.M., Schoonheydt, R.A.: Recent progress in diffuse reflectance spectroscopy of supported metal oxide catalysts. Catalysis Today 49(4), 441-451 (1999).

30. Lamberti, C., Zecchina, A., Groppo, E., Bordiga, S.: Probing the surfaces of heterogeneous catalysts by in situ IR spectroscopy. Chemical Society Reviews 39(12), 4951-5001 (2010).

31. Marberger, A., Ferri, D., Elsener, M., Kröcher, O.: The Significance of Lewis Acid Sites for the Selective Catalytic Reduction of Nitric Oxide on Vanadium-Based Catalysts. Angewandte Chemie International Edition 55(39), 11989-11994 (2016).

32. Sridhar, M., Ferri, D., van Bokhoven, J.A., Kröcher, O.: Water-assisted oxygen activation during gold-catalyzed formic acid decomposition under SCR-relevant conditions. Journal of Catalysis 349, 197-207 (2017). 
33. Nuguid, R.J.G., Ferri, D., Marberger, A., Nachtegaal, M., Kröcher, O.: Modulated Excitation Raman Spectroscopy of $\mathrm{V}_{2} \mathrm{O}_{5} / \mathrm{TiO}_{2}$ : Mechanistic Insights into the Selective Catalytic Reduction of NO with $\mathrm{NH}_{3}$. ACS Catalysis 9(8), 6814-6820 (2019).

34. Fogler, H.S.: Chapter 13: Distribution of Residence Times for Chemical Reactors. In: Elements of Chemical Reaction Engineering. pp. 867-944. Prentice Hall, Upper Saddle River, NJ (2005).

35. Marberger, A., Petrov, A.W., Steiger, P., Elsener, M., Kröcher, O., Nachtegaal, M., Ferri, D.: Time-resolved copper speciation during selective catalytic reduction of NO on Cu-SSZ-13. Nature Catalysis 1(3), 221-227 (2018).

36. Baurecht, D., Fringeli, U.P.: Quantitative modulated excitation Fourier transform infrared spectroscopy. Review of Scientific Instruments 72(10), 3782-3792 (2001).

37. Ohsaka, T., Izumi, F., Fujiki, Y.: Raman spectrum of anatase, TiO2. Journal of Raman Spectroscopy 7(6), 321-324 (1978).

38. Frank, O., Zukalova, M., Laskova, B., Kürti, J., Koltai, J., Kavan, L.: Raman spectra of titanium dioxide (anatase, rutile) with identified oxygen isotopes $(16,17,18)$. Physical Chemistry Chemical Physics 14(42), 14567-14572 (2012).

39. Went, G.T., Oyama, S.T., Bell, A.T.: Laser Raman spectroscopy of supported vanadium oxide catalysts. The Journal of Physical Chemistry 94(10), 4240-4246 (1990).

40. Wachs, I.E., Weckhuysen, B.M.: Structure and reactivity of surface vanadium oxide species on oxide supports. Applied Catalysis A: General 157(1), 67-90 (1997).

41. Tronconi, E., Nova, I., Ciardelli, C., Chatterjee, D., Weibel, M.: Redox features in the catalytic mechanism of the "standard" and "fast" $\mathrm{NH}_{3}-\mathrm{SCR}$ of $\mathrm{NO}_{\mathrm{x}}$ over a V-based catalyst investigated by dynamic methods. Journal of Catalysis 245(1), 1-10 (2007).

42. Giakoumelou, I., Fountzoula, C., Kordulis, C., Boghosian, S.: Molecular structure and catalytic activity of $\mathrm{V}_{2} \mathrm{O}_{5} / \mathrm{TiO}_{2}$ catalysts for the SCR of $\mathrm{NO}$ by $\mathrm{NH}_{3}$ : In situ Raman spectra in the presence of $\mathrm{O}_{2}, \mathrm{NH}_{3}, \mathrm{NO}, \mathrm{H}_{2}, \mathrm{H}_{2} \mathrm{O}$, and $\mathrm{SO}_{2}$. Journal of Catalysis 239(1), 1-12 (2006).

43. Negri, C., Signorile, M., Porcaro, N.G., Borfecchia, E., Berlier, G., Janssens, T.V.W., Bordiga, S.: Dynamic $\mathrm{Cu}^{\mathrm{II}} / \mathrm{Cu}^{\mathrm{I}}$ speciation in Cu-CHA catalysts by in situ Diffuse Reflectance UV-vis-NIR spectroscopy. Applied Catalysis A: General 578, 1-9 (2019).

44. Nanba, T., Chino, T., Masukawa, S., Uchisawa, J., Obuchi, A.: Total Oxidation of Toluene over $\mathrm{Cu} / \mathrm{TiO} 2 / \mathrm{SiO} 2$. Bulletin of the Chemical Society of Japan 86(4), 534539 (2013).

45. Long, R.Q., Yang, R.T.: Characterization of Fe-ZSM-5 Catalyst for Selective Catalytic Reduction of Nitric Oxide by Ammonia. Journal of Catalysis 194(1), 80-90 (2000).

46. Schwidder, M., Heikens, S., De Toni, A., Geisler, S., Berndt, M., Brückner, A., Grünert, W.: The role of $\mathrm{NO}_{2}$ in the selective catalytic reduction of nitrogen oxides over FeZSM-5 catalysts: Active sites for the conversion of $\mathrm{NO}$ and of $\mathrm{NO} / \mathrm{NO}_{2}$ mixtures. Journal of Catalysis 259(1), 96-103 (2008). 
Table 1. Residence time distribution characteristics of the spectroscopic cell

\begin{tabular}{|l|r|r|r|r|r|r|}
\cline { 2 - 8 } \multicolumn{1}{c|}{} & \multicolumn{9}{c|}{ Flow rate } \\
\cline { 2 - 8 } \multicolumn{1}{c|}{} & \multicolumn{2}{c|}{$100 \mathrm{~mL} \cdot \mathrm{min}^{-1}$} & \multicolumn{2}{c|}{$50 \mathrm{~mL} \cdot \mathrm{min}^{-1}$} & \multicolumn{2}{c|}{$25 \mathrm{~mL} \cdot \mathrm{min}^{-1}$} \\
\cline { 2 - 8 } \multicolumn{1}{c|}{} & Bypass & Cell & \multicolumn{1}{c|}{ Bypass } & \multicolumn{1}{c|}{ Cell } & Bypass & Cell \\
\hline $\mathrm{t}_{\mathrm{m}}(\mathrm{s})$ & 21.6 & 22.9 & 23.8 & 26.2 & 28.4 & 31.2 \\
\hline t90 (s) & 7.2 & 13.7 & 4.8 & 6.9 & 2.8 & 3.8 \\
\hline t95 (s) & 11.7 & 24.5 & 8.0 & 12.2 & 5.0 & 6.5 \\
\hline t99 (s) & 65.3 & 113.4 & 51.0 & 79.6 & 36.6 & 47.3 \\
\hline
\end{tabular}

Legend: $\mathrm{t}_{\mathrm{m}}=$ mean residence time; $\mathrm{t}_{90}=$ time for the MS signal to drop by $90 \%$ of the maximum value; t $_{95}=$ time for the MS signal to drop by $95 \%$ of the maximum value; t $99_{9}=$ time for the MS signal to drop by $99 \%$ of the maximum value 


\section{Figure Captions}

Figure 1. Design of the spectroscopic cell. All the detailed specifications and measurements are given in Figures S-1 to S-4.

Figure 2. Single beam spectra of the sample position (optimized height) and of the window position (non-optimized height) as a function of the cell position in the z-axis.

Figure 3. Normalized residence time distribution profiles of $2 \mu \mathrm{L}$ NO pulsed in a gas feed of Ar through the spectroscopic cell and bypass at room temperature and atmospheric pressure in dependence of the total flow: (a) $100 \mathrm{ml} \cdot \mathrm{min}^{-1}$, (b) $50 \mathrm{ml} \cdot \mathrm{min}^{-1}$, and (c) $25 \mathrm{ml} \cdot \mathrm{min}^{-1}$.

Figure 4. (a) Time-resolved Raman spectra and (b) the corresponding in-phase spectrum of $\mathrm{V}_{2} \mathrm{O}_{5} / \mathrm{TiO}_{2}$ at $250{ }^{\circ} \mathrm{C}$ during 30 -s pulses of $500 \mathrm{ppm} \mathrm{NO}$ in a gas feed of $500 \mathrm{ppm} \mathrm{NH}, 2$ vol $\% \mathrm{H}_{2} \mathrm{O}$ and 5 vol\% $\mathrm{O}_{2}$ balanced in Ar. (c) Time-resolved Raman spectra and (d) a selected phase-resolved spectrum of $2 \mathrm{wt} \% \mathrm{~V}_{2} \mathrm{O}_{5} / \mathrm{TiO}_{2}$ at $250{ }^{\circ} \mathrm{C}$ during 30 -s pulses of $\mathrm{Ar}$ in a gas feed of 2 vol $\% \mathrm{H}_{2} \mathrm{O}$ and 5 vol $\% \mathrm{O}_{2}$ balanced in Ar.

Figure 5. (a) Time-resolved DR-Vis spectra and (b) the corresponding in-phase spectrum of $1.6 \mathrm{wt} \% \mathrm{Cu}-\mathrm{SSZ}-13$ at $250{ }^{\circ} \mathrm{C}$ during 120 -s pulses of $1000 \mathrm{ppm}$ NO in a gas feed of 1000 ppm NH 3,2 vol $\% \mathrm{H}_{2} \mathrm{O}$ and 5 vol $\% \mathrm{O}_{2}$ balanced in Ar. (c) Time-resolved DR-Vis spectra and (d) a selected phase-resolved spectrum of $1.6 \mathrm{wt} \% \mathrm{Cu}-\mathrm{SSZ}-13$ at $250{ }^{\circ} \mathrm{C}$ during 120 -s pulses of $\mathrm{Ar}$ in a gas feed of $2 \mathrm{vol} \% \mathrm{H}_{2} \mathrm{O}$ and 5 vol $\% \mathrm{O}_{2}$ balanced in $\mathrm{Ar}$.

Figure 6. (a) Time-resolved DRIFT spectra and (b) the corresponding in-phase spectrum of $2.6 \mathrm{wt} \% \mathrm{Fe}-\mathrm{ZSM}-5$ at $250{ }^{\circ} \mathrm{C}$ during 60 -s pulses of $\mathrm{NO}$ in a gas feed of $1000 \mathrm{ppm} \mathrm{NH}, 2$ 
vol $\% \mathrm{H}_{2} \mathrm{O}$ and 5 vol $\% \mathrm{O}_{2}$ balanced in Ar. (c) Time-resolved DRIFT spectra and (d) a selected phase-resolved spectrum of $1 \mathrm{wt} \% \mathrm{Fe}-\mathrm{ZSM}-5$ at $250{ }^{\circ} \mathrm{C}$ during 60 -s pulses of Ar in a gas feed of $1000 \mathrm{ppm} \mathrm{NH}, 2$ vol\% $\mathrm{H}_{2} \mathrm{O}$ and 5 vol\% $\mathrm{O}_{2}$ balanced in Ar. Legend: $-\mathrm{OH}(\diamond), \mathrm{NH}_{3}$ adsorbed on Brønsted-Lowry sites $(\bullet), \mathrm{NH}_{3}$ adsorbed on Lewis sites $(\star), \mathrm{NO}^{+}(\#)$, and $-\mathrm{SO}_{4}$ ( $\square$ ). The peaks at 2360 and $2330 \mathrm{~cm}^{-1}$ originate from fluctuations in $\mathrm{CO}_{2}$ concentration in the environment of the sample compartment and not from any adsorbed species. 


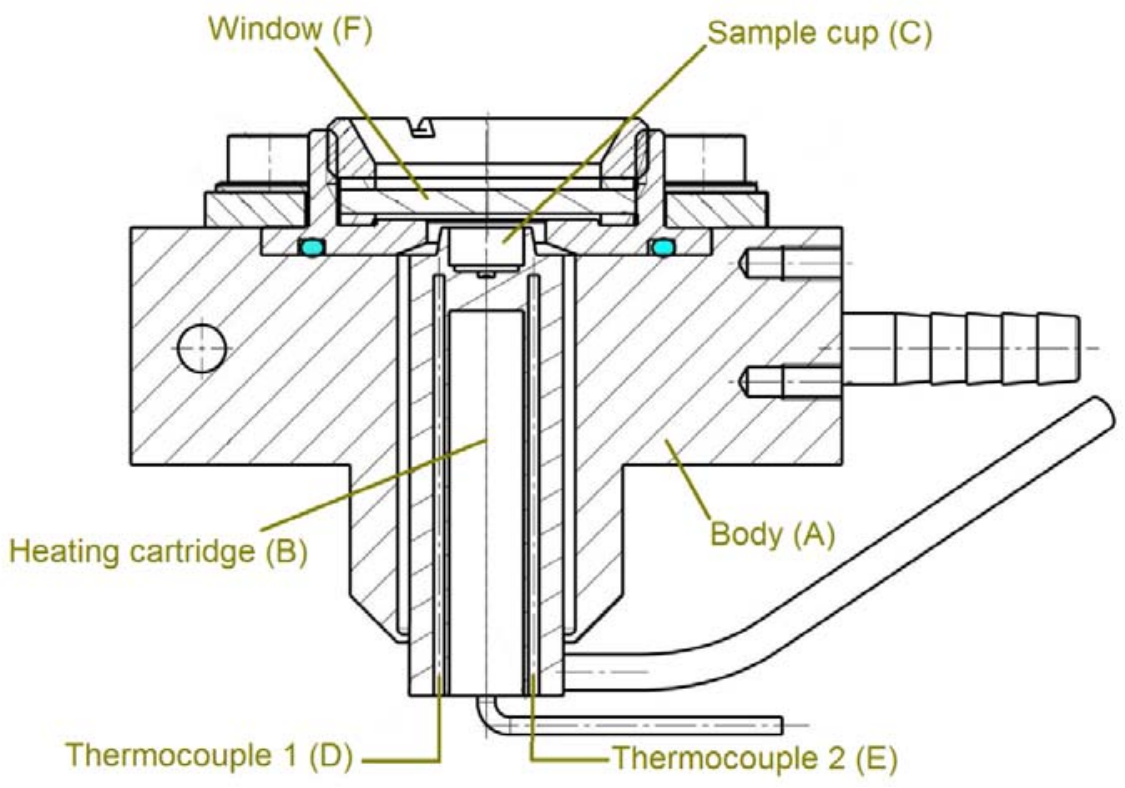

Figure 1 


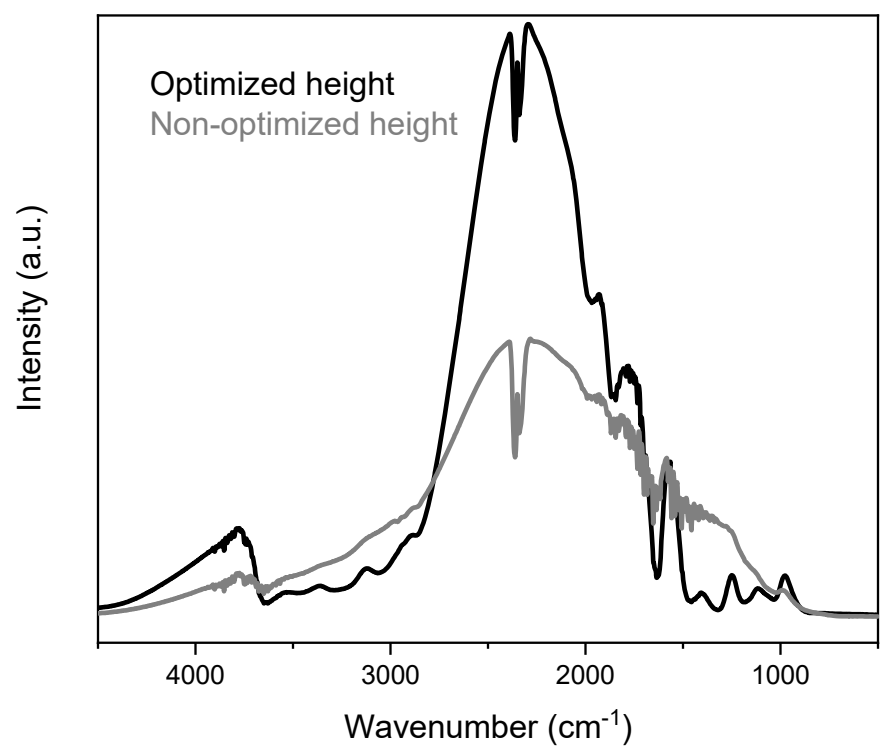

Figure 2 

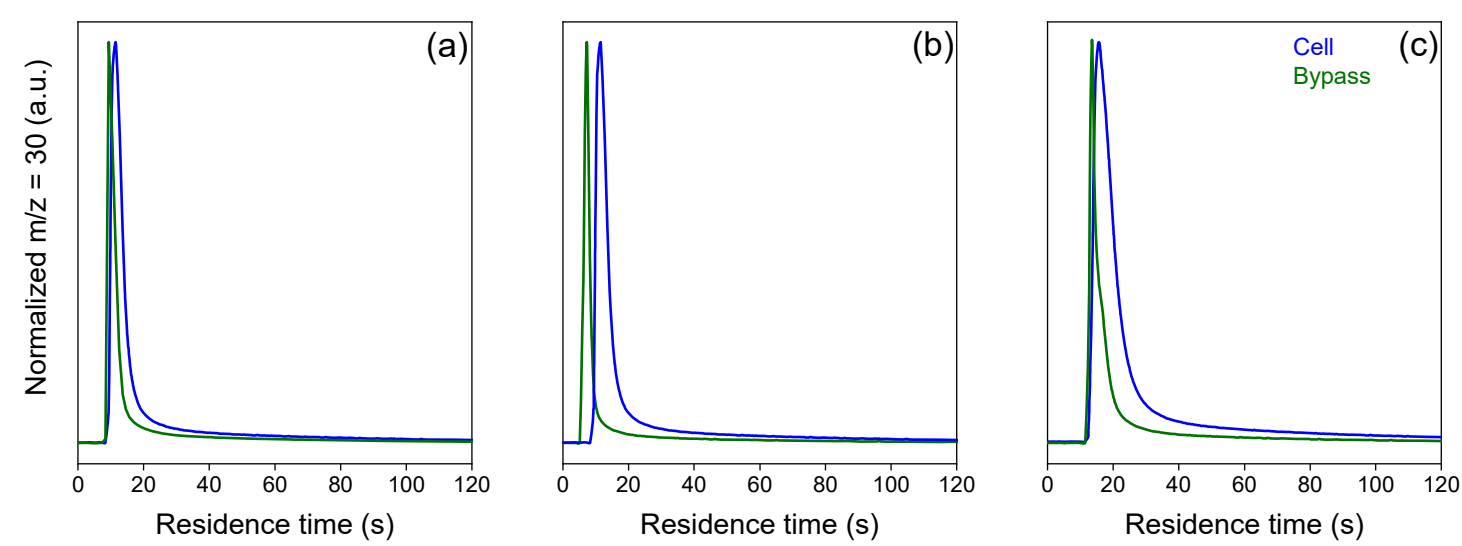

Figure 3 

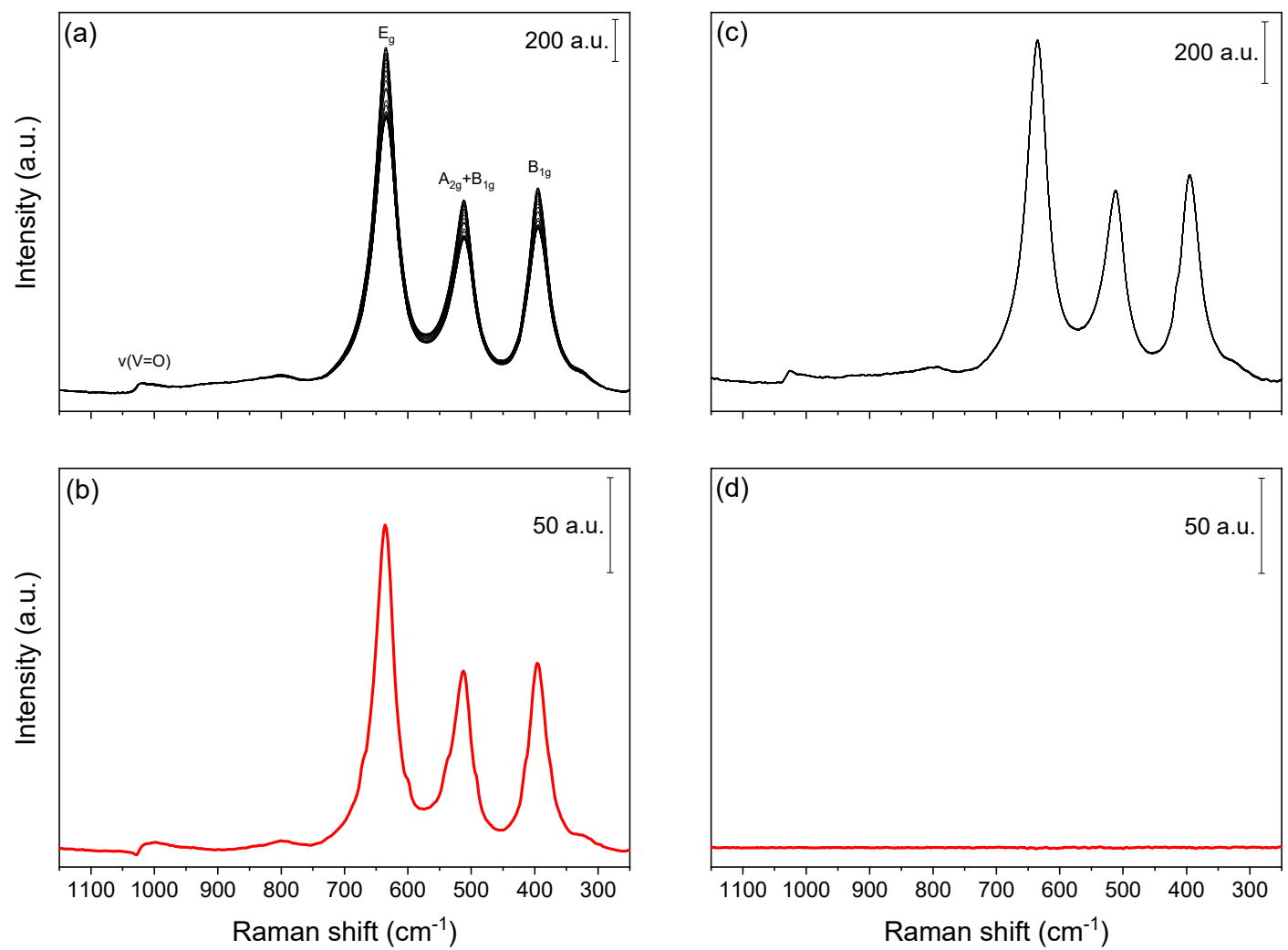

Figure 4 

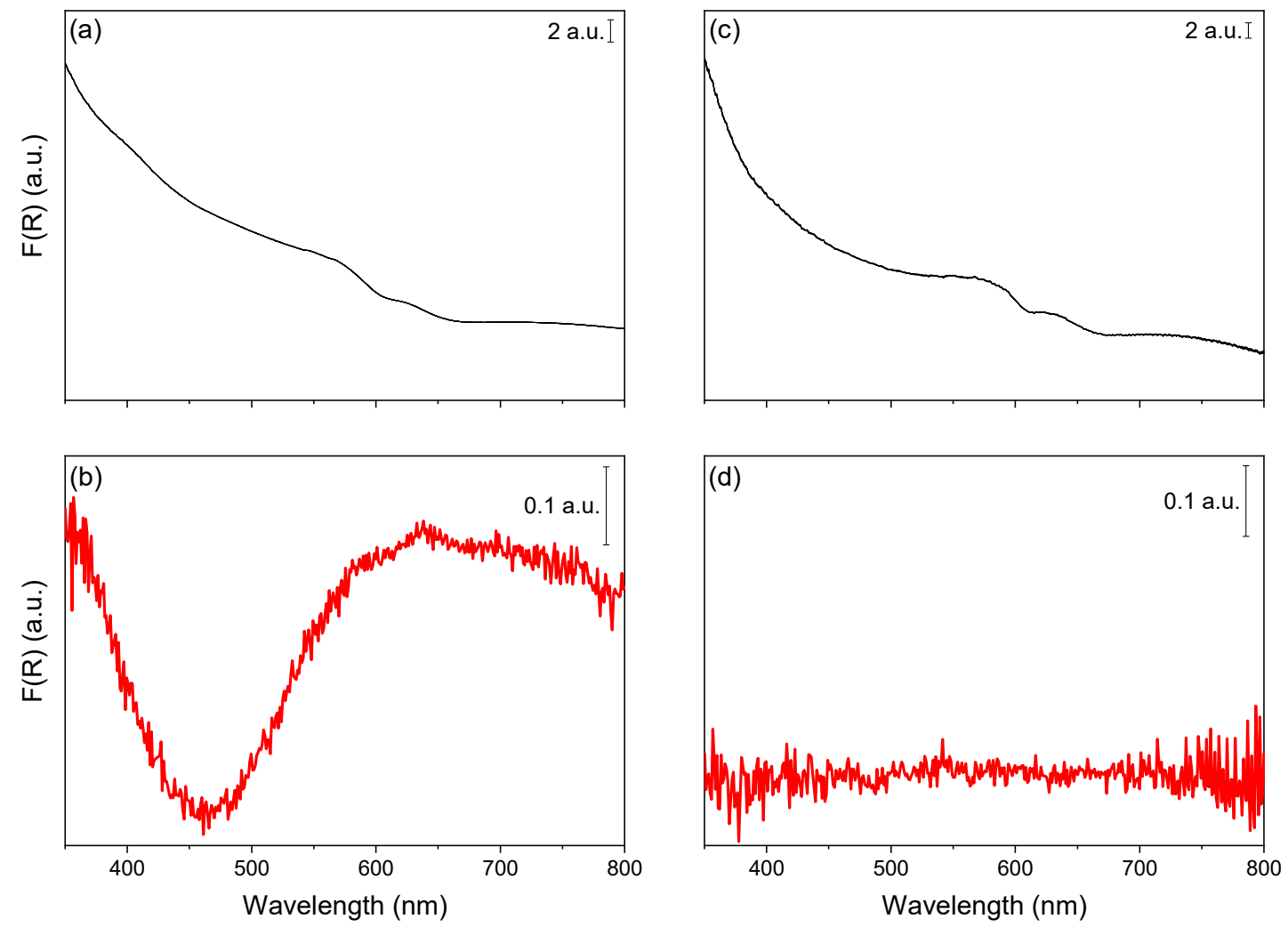

Figure 5 

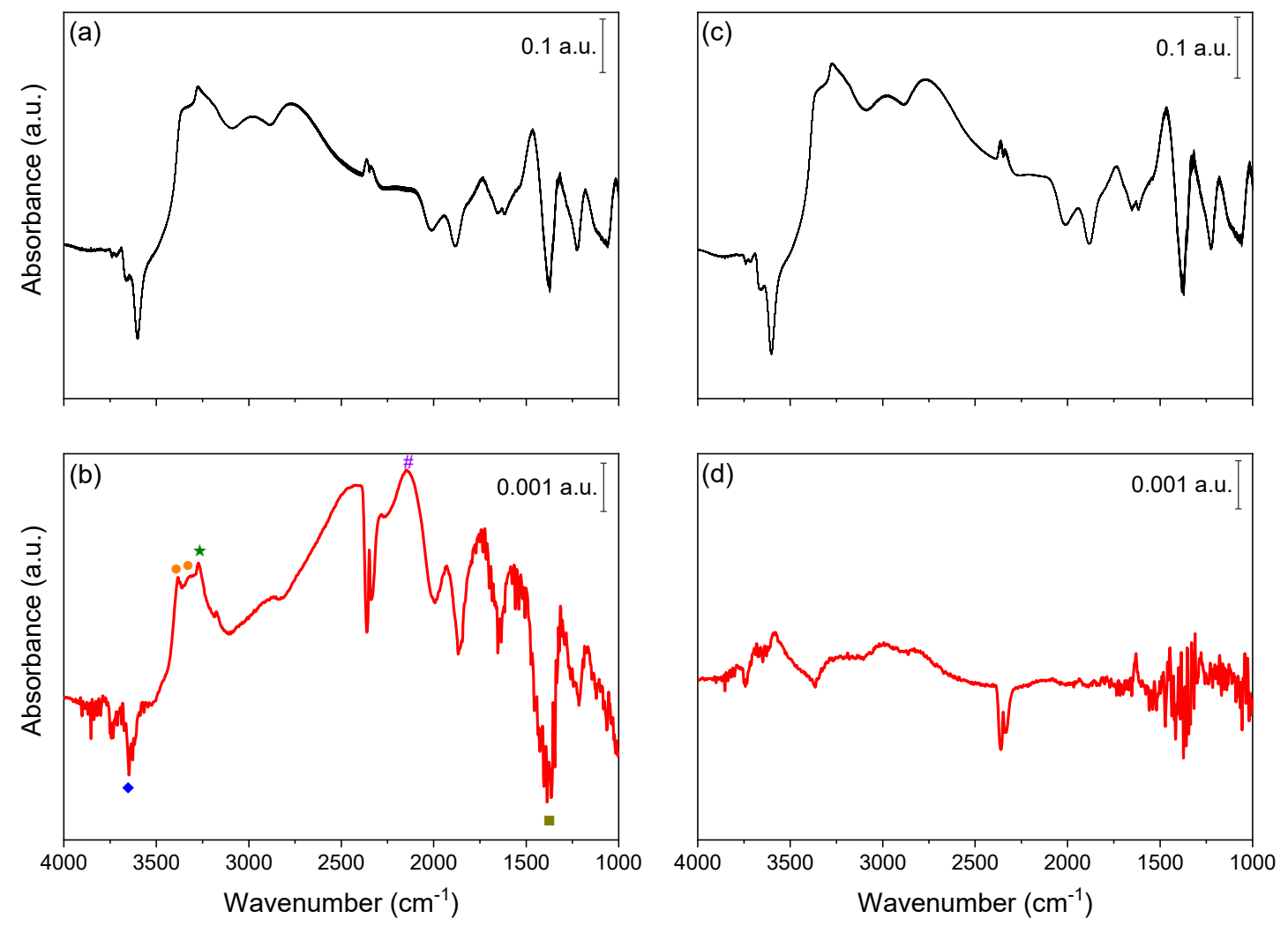

Figure 6 